\title{
An Accurate Battery Charger SEPIC-Coupled Inductor Using Fuzzy Type 2
}

\author{
Berliana Rahma Putri ${ }^{1, a}$, Indhana Sudiharto ${ }^{1, b}$, and Farid Dwi Murdianto ${ }^{1, c}$ \\ ${ }^{1}$ Electrical Engineering Department Politeknik Elektronika Negeri Surabaya, Surabaya Indonesia \\ a berlianar3@gmail.com, \\ b indhana@eepis-its.edu, \\ c, ${ }^{*}$ farid@ @ens.ac.id (Corresponding Author)
}

\begin{abstract}
Recently, the needs of electrical energy have increased in line with the increasing population in Indonesia. Electrical in order to save the use of fossil energy, renewable is used, namely solar energy. Solar energy depends on the conditions of sunlight and the temperature of the solar panel. So, if the solar panel is directly connected to the battery, it will cause the battery be damaged. To overcome this, a controlled DC-DC converter is needed to stabilize the solar panel output before connecting to the battery. The DC-DC converter that used is a SEPIC coupled inductor converter, this converter has the ability to increase efficiency, the output polarity is not reversed, and avoid input current ripple. The control used to adjust the output of the SEPIC converter is a type 2 fuzzy logic controller because it has ability to find a set point value faster than other control logics and can handle uncertainty better than a type 1 fuzzy logic controller. The output of the SEPIC converter is used for charging lithium ion battery with a capacity $12 \mathrm{~V} 21 \mathrm{Ah}$. The output value of the SEPIC converter is $12.6 \mathrm{~V}$ for charging voltage and $7 \mathrm{~A}$ for charging current. The method used for battery charging is the constant current constant voltage method (cc-cv).
\end{abstract}

Keywords-SEPIC Coupled Inductor, Type 2 Fuzzy Logic Control, Constant Current-Constant Voltage

\section{Introduction}

Currently, there are many developments of the energy storage using batteries and solar panels as energy sources [1]. The uses of solar energy sources can reduce the uses of fossil energy. Because the output of solar panel is fluctuating due to the charging value of solar radiation [2]. Therefore, to store the energy produced during the irradiation process, a battery is needed [3] So, DC-DC converter is needed to adjust the output of the solar panel, which will be used for charging the battery and the battery is not damaged quickly. The DC-DC converter is SEPIC coupled inductor has the ability to avoid input current ripple, reduce load voltage ripple, can increase converter efficiency, output polarity nit reversed, and can produce the output voltage greater or lower than the input voltage [4]. Because the converter gets a voltage source from the solar panel, the duty cycle of the converter will be adjusted to match the battery charging process. The control uses type 2 fuzzy logic controller. The advantages of using FLC type 2 are that it is more reliable and stable, has more factor control errors than the other controls, handles uncertainty better than FLC type 1 and can reach set point values faster than the other controls [5]. The FLC type 2 method uses to this study is Sugeno method, which produces output in the form of a constant or linear equation [6]. There are many methods of charging the battery, one method of charging battery is constant current constant voltage method (CC-CV), this method is very appropriate for the battery charging process because this method causes the battery to last longer [7]. Therefore, in this research, battery charging will be implemented and designed using the constant current constant voltage method which is controlled by FLC type 2 and will regulate the duty cycle of the SEPIC coupled inductor converter.

\section{Research Methodology}

\section{A. Research Method}

. This research includes solar panel as a power source for input of the SEPIC coupled inductor converter, CCCV method for battery charging, and type 2 fuzzy logic control will regulate the output of the converter [8]. Figure 1. shows the diagram block of the system. 


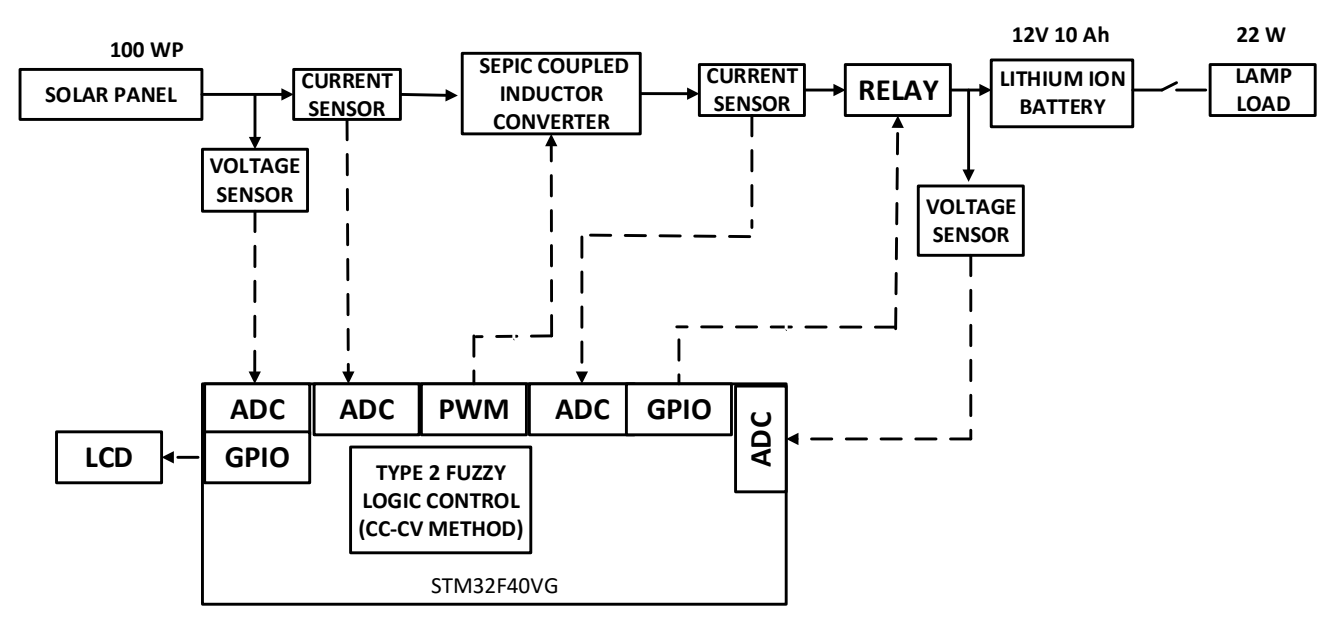

Figure 1. Diagram block system

\section{B. Constant Current Constant Voltage}

One of the electrical devices is the battery which there is the process of electrochemical that works reverse and forward so, the process of charging and discharging is a process that occurs inside the battery. The conversion of chemical energy into electrical energy is called the discharge process. The process of regenerating electrodes in a battery that conducts electric current in the opposite direction of the cell is called the charging process. There are many battery charging methods such as constant current $(\mathrm{CC})$, constant voltage $(\mathrm{CV})$, constant trickle (CTC), and constant current constant voltage (CC-CV) [9].

Constant trickle is a method of battery charging by charging on discharge rate, so that the battery is maintained in a full condition. Constant current is a method of charging the battery with a constant current until the maximum voltage is reached at the battery voltage. Constant voltage is a method of charging the battery with a constant voltage until the current is cut off due to reduced charging current. This battery charging process will prevent the battery from changing excessively because it maintains a constant voltage to its maximum voltage value, but it takes a longer time to charge the battery with constant voltage than the constant current method.

The last method is constant current constant voltage, that works by charging the battery in the first step using constant current mode, after reaching the maximum voltage of the battery voltage the charging process moves to constant voltage mode until the current is cut off due to reduced charging current. Using the method of constant current constant voltage, battery charging will be according to its full capacity. Charging the battery begins with a constant current and continues with a constant voltage until the capacity of the battery is met. Figure 2 . shows the battery charging process using CC-CV method [9].

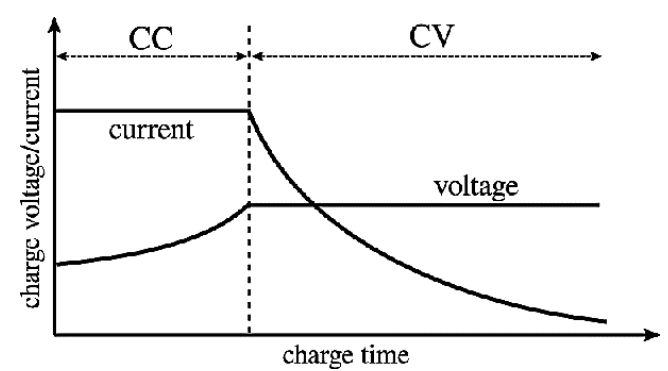

Figure 2. Graph of battery charging with CC-CV method [9]

\section{SEPIC Coupled Inductor Converter}

The SEPIC converter is a type of DC-DC converter that can generate a smaller or higher output voltage than the input voltage by varying the value of duty cycle [10]. This converter is similar to a buck - boost converter. The advantages of using a SEPIC converter than using buck boost converter is that the output polarity is not reversed, the efficiency of the converter is higher, the voltage ripple and current ripple are better than the buck-boost converter $[11,12]$. In this paper, a SEPIC converter with a coupled inductor is used, which in this converter only uses one coupled inductor. The purpose of using a coupled inductor is to avoid input current ripple and converter efficiency can be increased. Figure 3 shows the SEPIC coupled inductor converter circuit. 


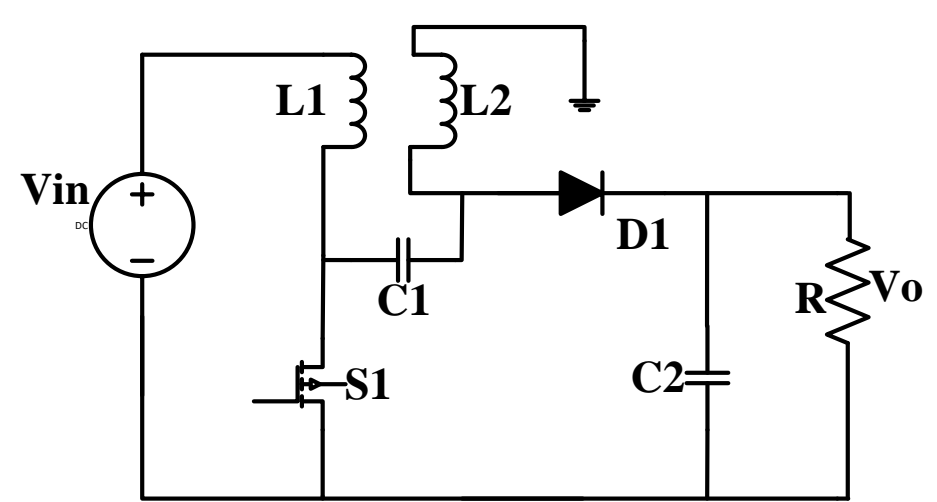

Figure 3. SEPIC coupled inductor converter circuit

In this research the SEPIC converter input voltage is obtained from the solar panel and the converter output will be connected to the battery. To calculate the value of the converter component will be explained in equations (1) to (6) [13].

$V_{O}=V_{\text {in }} \times \frac{D}{1-D}$

$L_{1}=\left(V_{I N}-\frac{L_{m} \times \Delta i L_{2} \times i_{2} \times f}{D}\right) \times\left(\frac{D}{\Delta i L_{1} \times i_{1} \times f}\right)$

$L_{2}=\frac{V_{O} \times(1-D)}{f\left(\Delta i L_{1} \times i_{1}+\Delta i L_{2} \times i_{2}\right)}$

$L_{m}=L_{2}$

$C_{1}=\frac{V_{O} \times D}{R \times \Delta V c_{1} \times f}$

$C_{2}=\frac{V_{O} \times D}{R \times \Delta V_{O} \times f}$

After knowing the equation to find the value of the converter component, table 1 shows the using parameters in this research [14].

Table 1. The Parameter of SEPIC Coupled Inductor Converter

\begin{tabular}{|c|c|}
\hline Parameter & Value \\
\hline Input voltage & $17.5 \mathrm{~V}$ \\
\hline Output voltage & $12.6 \mathrm{~V}$ \\
\hline Frequency switching & $100 \mathrm{kHz}$ \\
\hline Ripple current & $10 \%$ \\
\hline Ripple voltage & $10 \%$ \\
\hline Inductor 1 (L1) & $55 \mu \mathrm{H}$ \\
\hline Inductor 2 (L2) & $55 \mu \mathrm{H}$ \\
\hline Magnetizing inductor (Lm) & $55 \mu \mathrm{H}$ \\
\hline Capacitor 1 (C1) & $594 \mu \mathrm{F}$ \\
\hline Capacitor 2 (C2) & $126.5 \mu \mathrm{F}$ \\
\hline
\end{tabular}

\section{Type 2 Fuzzy Logic Control}

Because there is a weakness in type 1 fuzzy logic control, which is that it cannot handle the uncertainty associated with the input and output membership functions, therefore the performance of type 1 fuzzy logic control is reduced [15]. To overcome this problem, in 1975 Lotfi Zadeh has developed and introduced type 2 fuzzy logic control. The system of type 2 fuzzy logic control has the same characteristics as the type 1 fuzzy logic control, which uses an if-then rule basis. In addition, to change the type 2 fuzzy set to produce an output value, the type 2 fuzzy logic control has a reduction type stage. In general, the type 2 fuzzy logic control system has stages of fuzzification, rule base, fuzzy inference, reduction type, and defuzzification [16]. Figure 4. shows the diagram block of type 2 fuzzy logic control system.

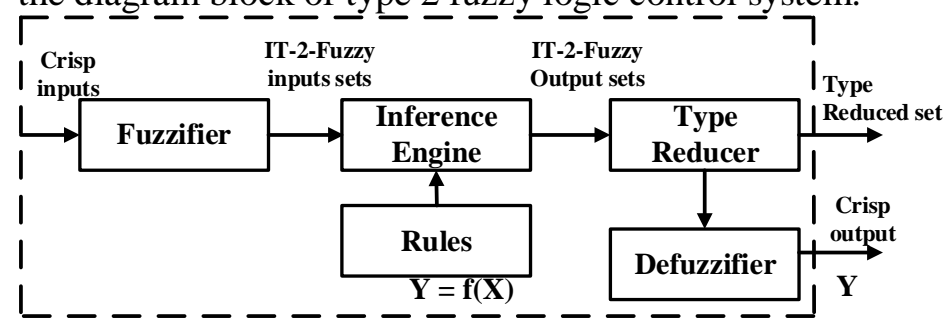

$\overline{\text { Figure }} \overline{4 .} \overline{\text { Diagram block of type }} \overline{2}$ fuzzy logic control system

The crisp input values $x=\left[x_{1}, \ldots \ldots, x_{n}\right]$ are mapped by the fuzzifier into the fuzzy set space. Figure 5 shows the projection of the input value on the membership function, the resulting interval represents the intersection of the upper and lower bounds [17]. Knowledge base principles are covered by the rule base block into "if ... then" statements. The conditional statement has a general form like equation (7) with the consideration that the IT2 system contains $\mathrm{N}$ rules [18].

$R^{N}: I F x_{1}$ is $\widetilde{F_{l}^{N}}$ and ...... and $x_{1}$ is $\widetilde{F_{l}^{N}}$ THEN $y$ is $Y^{N}$

Where $\widetilde{F_{l}^{N}}(I=0 \ldots . . i)$ are the IT2 fuzzy set terms modelling, and the lower and upper consequences $\left[\underline{y^{N}}, \overline{y^{N}}\right]$ represent the interval bounded of $Y^{N}[5]$. calculate the firing interval $\left[f^{N}, \overline{f^{N}}\right]$ by combining the preliminary rules based on the intersection of the upper $\operatorname{MF} \bar{\mu}_{f_{j}^{N}}\left(x_{j}\right)$ and lower $\operatorname{MF} \underline{\mu}_{f_{j}^{N}}\left(x_{j}\right)$ inputs. The use of $i_{t h}$ rule expressions, the formulation of the calculation of the shooting point on the left and right sides is calculated by the equations (8) to (9) $[19,20]$.

$$
f^{N}=\mu_{f_{1}^{N}}\left(x_{1}\right) \times \mu_{f_{2}^{N}}\left(x_{2}\right) \times \ldots \times \mu_{f_{n}^{N}}\left(x_{n}\right)
$$


$\bar{f}^{N}=\bar{\mu}_{f_{1}^{N}}\left(x_{1}\right) \times \bar{\mu}_{f_{2}^{N}}\left(x_{2}\right) \times \ldots \times \bar{\mu}_{f_{n}^{N}}\left(x_{n}\right)$

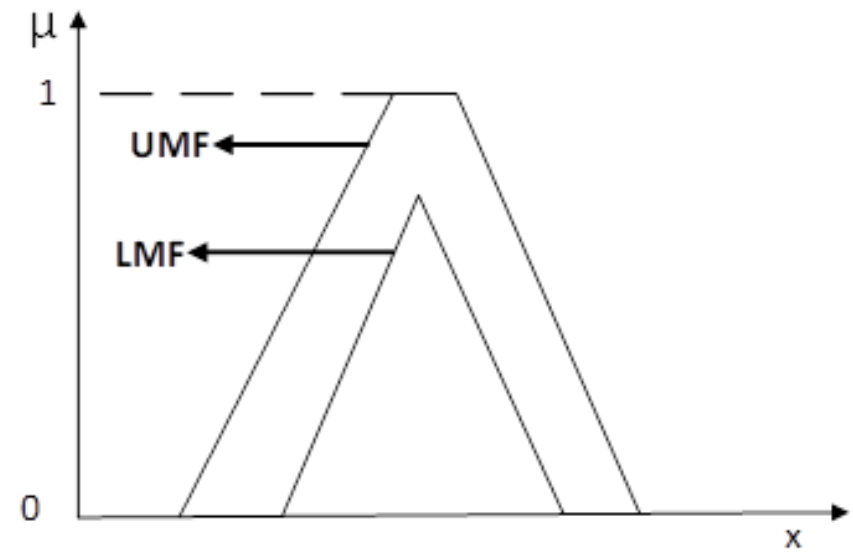

Figure 5. An example of the upper and lower membership function

The next process is to reduce the type 2 fuzzy set sequentially before the defuzzification process. This process uses a type reduction algorithm by combining the firing interval with the appropriate rules [21]. To determine the final result can be seen in the questions (10) to (11).

$y_{l}=\frac{\sum_{n=1}^{L} \bar{f}^{n} \underline{y}^{n}+\sum_{n=L+1}^{N} \underline{f}^{n} \underline{y}^{n}}{\sum_{n=1}^{L} \bar{f}^{n}+\sum_{n=L+1}^{L} \underline{f}^{n}}$

$y_{r}=\frac{\sum_{n=1}^{R} f^{n} \bar{y}^{n}+\sum_{n=R+1}^{N} \bar{f}^{n} \bar{y}^{n}}{\sum_{n=1}^{R} \underline{f}^{n}+\sum_{n=R+1}^{L} \bar{f}^{n}}$

$f^{n}$ and $f^{n}$ are the firing values whose right and left sides are adjusted to most of points, while the change in the value of the accumulation function of the upper membership to the lower membership value is represented by $R$ and $N$, and vice versa [22]. To find the point of transition of the right and left functions using an iterative KM algorithm. Extensive and successive calculation are required when using the KM algorithm, this method is the most effective and widely used method. The crisp output value obtained in the defuzzification process with the equation (12) [23].

$y_{d e f}=\frac{y_{l}+y_{r}}{2}$

\section{Results and Discussion}

In this section, explaining about testing of the SEPIC coupled inductor converter controlled by type 2 fuzzy logic control [24]. Type 2 fuzzy logic control is used to adjust the output of the SEPIC coupled inductor converter so that the current is maintained constant at 7A during battery charging and also maintains a constant voltage of $12.6 \mathrm{~V}$ when the battery is fully charged. Figure 6 . shows the design of the type 2 fuzzy logic control variable.

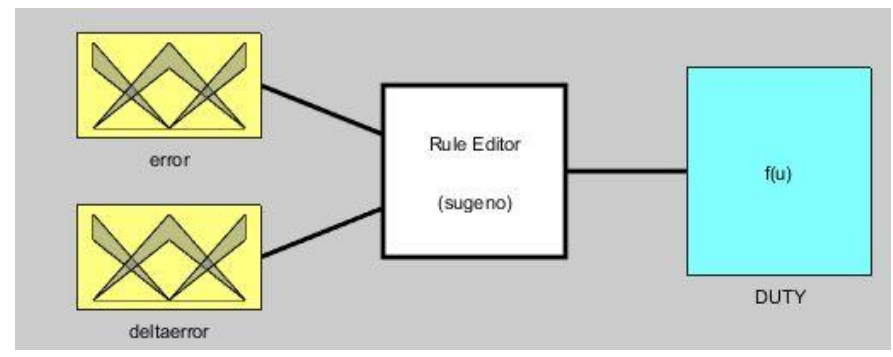

Figure 6. Design of input and output variable type 2 fuzzy logic control

Figure 6. shows the design of input and output variables of type 2 fuzzy logic control which is used to control constant current and constant voltage, for constant current and constant voltage it has 2 input variables, namely error and delta error and for output variable only 1, namely duty. Figure 7-10 shows the design range error and delta error of constant current and constant voltage.

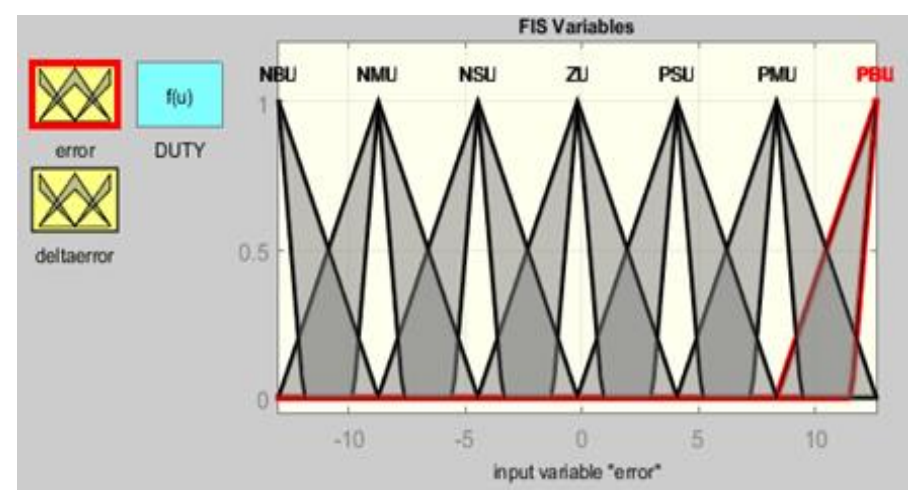

Figure 7. Design of error for constant voltage

Figure 7. shows the design of error for a constant voltage with range of error from -13 to 12.6. After knowing the design of error for a constant voltage in Figure 8. shows the design of delta error for a constant voltage. 


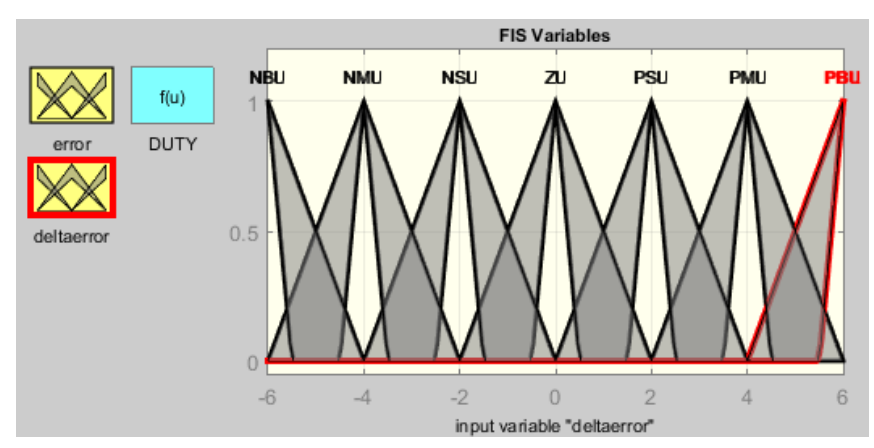

Figure 8. Design of delta error for constant voltage

Figure 8. shows the design of delta error for a constant voltage with range of delta error from -6 to 6 . After knowing the design of error and delta error for a constant voltage, in figure 9. and figure 10. shows the design of error and delta error for a constant current.

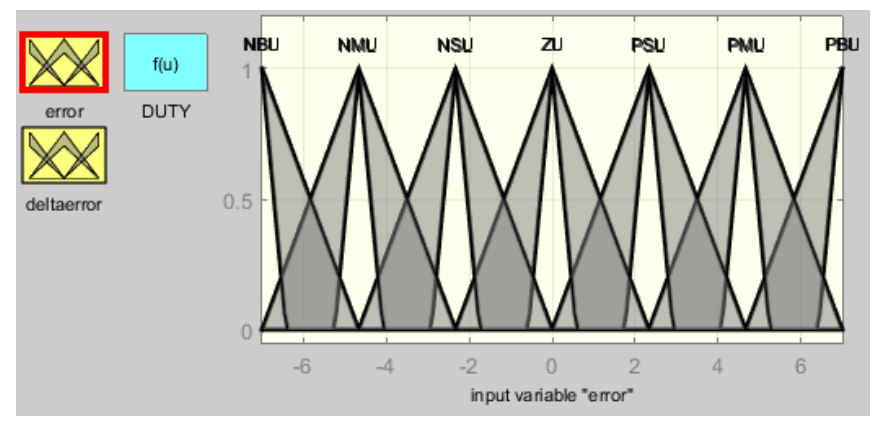

Figure 9. Design of error for constant current

Figure 9 shows the design of error for a constant current with range of delta error from -7 to 7 .

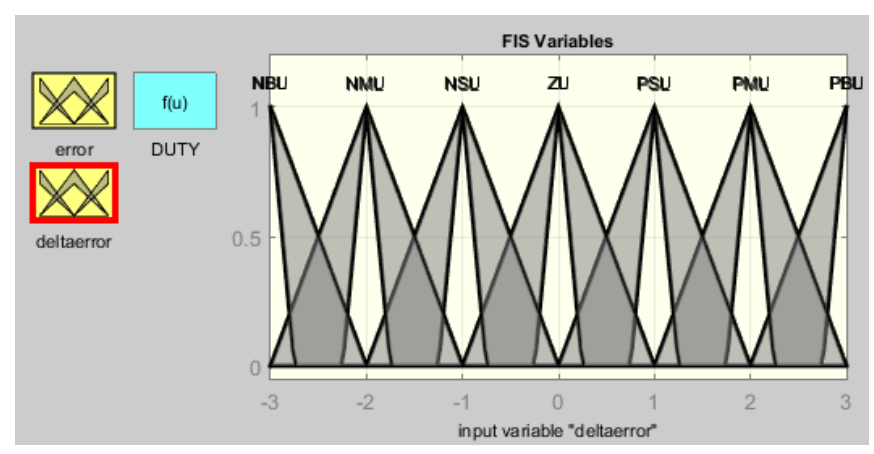

Figure 10. Design of delta error for constant current
Figure 10. shows the design of delta error for a constant current with range of delta error from -3 to 3 .

From Figure 7-10, each of the fuzzification inputs, uses 7 triangular membership functions. The 7 membership functions of the input and output are Negative Big (NB), Negative Medium (NM), Negative Small (NS), Zero (Z), Positive Small (PS), Positive Medium (PM), and Positive Big (PB). There are 49 rules generated by 7 combinations of membership functions formed from the input error and delta error variables. The results of the combination of rules are shown in table 2 .

Table 2. Rule base of type 2 fuzzy logic control

\begin{tabular}{|c|c|c|c|c|c|c|c|}
\hline E/dE & NB & NM & NS & Z & PS & PM & PB \\
\hline NB & NB & NB & NB & NB & NM & NS & Z \\
\hline NM & NB & NB & NM & NM & NS & Z & PS \\
\hline NS & NB & NM & NS & NS & Z & PS & PM \\
\hline Z & NB & NM & NS & Z & PS & PM & PB \\
\hline PS & NM & NS & Z & PS & PS & PM & PB \\
\hline PM & NM & Z & PS & PM & PM & PB & PB \\
\hline PB & Z & PS & PM & PM & PB & PB & PB \\
\hline
\end{tabular}

In this simulation, the battery charging current is $7 \mathrm{~A}$ in constant current mode and the voltage when the battery is fully charged is $12.6 \mathrm{~V}$. In the lithium ion battery charging stage, when the battery is still empty, the constant current method works with a constant current value of $7 \mathrm{~A}$ and if the battery is in a state almost fully charged, then the automatic switch in the control circuit will work by changing the charging method from constant current to constant voltage. The result of the simulation of the battery charging circuit using the constant currentconstant voltage method using type 2 fuzzy logic control is shown in Figure 11. 

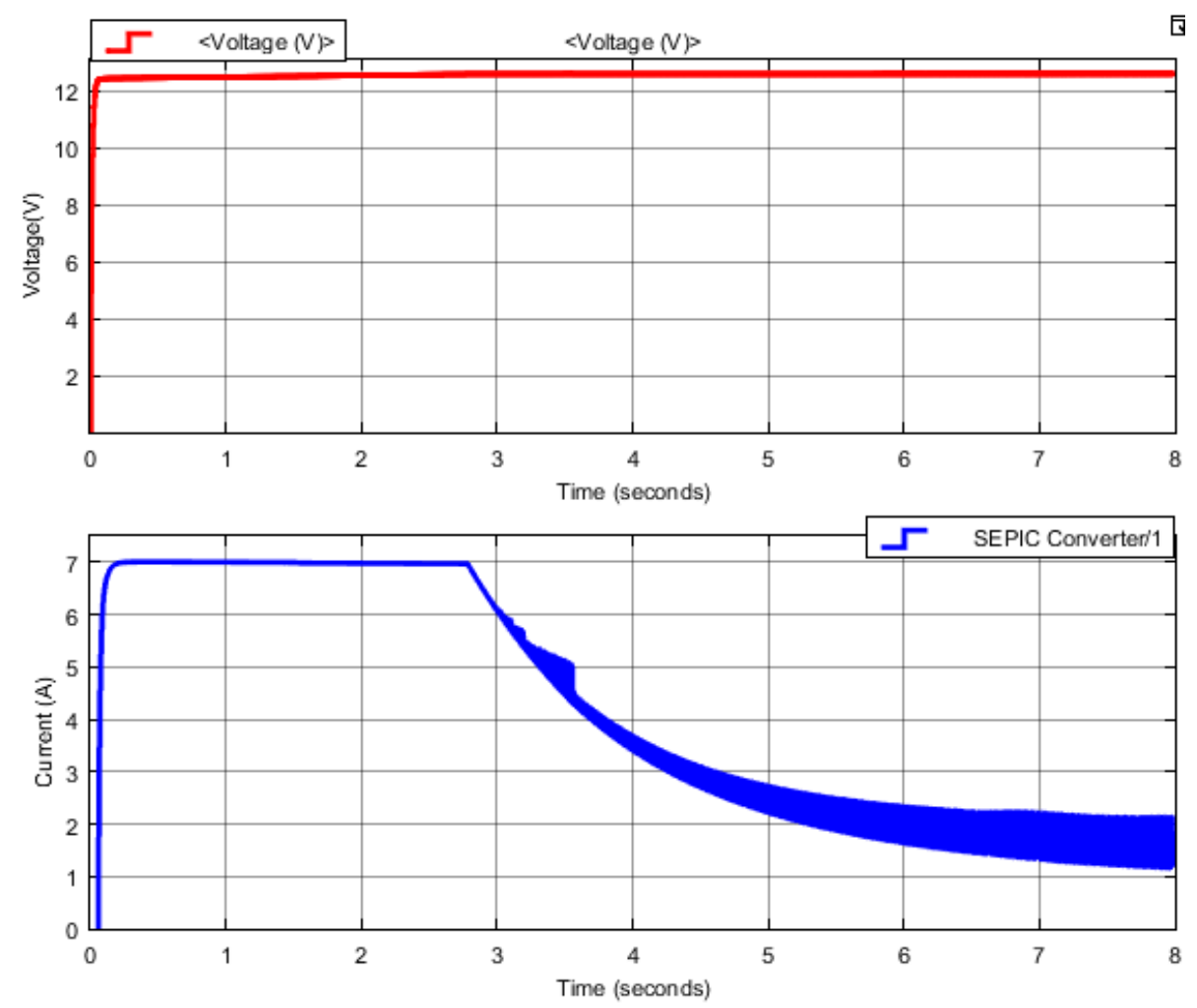

Figure 11 . Battery charge simulation waveform with constant current-constant voltage

Table 3. Battery charging data with SOC value in STC condition

\begin{tabular}{|c|c|c|c|}
\hline $\begin{array}{c}\text { Input voltage } \\
(\mathrm{V})\end{array}$ & $\begin{array}{c}\text { SOC } \\
(\%)\end{array}$ & $\begin{array}{c}\text { Output current } \\
(\mathrm{A})\end{array}$ & $\begin{array}{c}\text { Output voltage } \\
(\mathrm{V})\end{array}$ \\
\hline 19.78 & 30 & 7 & 11.9 \\
\hline 19.68 & 40 & 7 & 11.95 \\
\hline 19.44 & 50 & 7 & 12.46 \\
\hline 20 & 60 & 1.775 & 12.6 \\
\hline
\end{tabular}

From figure 11 the displacement from constant current mode to constant voltage mode when the SOC of the battery is $60 \%$ with a voltage value of $12.6 \mathrm{~V}$ and the current value decreases from a constant value of $7 \mathrm{~A}$ to $1.775 \mathrm{~A}$ and continues to decrease until it approaches zero. In Table 3 shows the data of battery charging with SOC value in STC condition.
After performing the integration simulation, to prove that the control works according to the set points, the solar panel irradiation value is varied. This proves the performance of type 2 fuzzy logic control. Figure 12 shows the disturbance of the irradiation value on the solar panel where the irradiation value is reduced to $900 \mathrm{~W} / \mathrm{m}^{2}$ from $2^{\text {nd }} \mathrm{s}$ to $4^{\text {th }} \mathrm{s}$. After that, figure 13. shows the simulation results from the $\mathrm{CC}-\mathrm{CV}$ graph with the disturbance of the irradiation value with a value $900 \mathrm{~W} / \mathrm{m}^{2}$. 


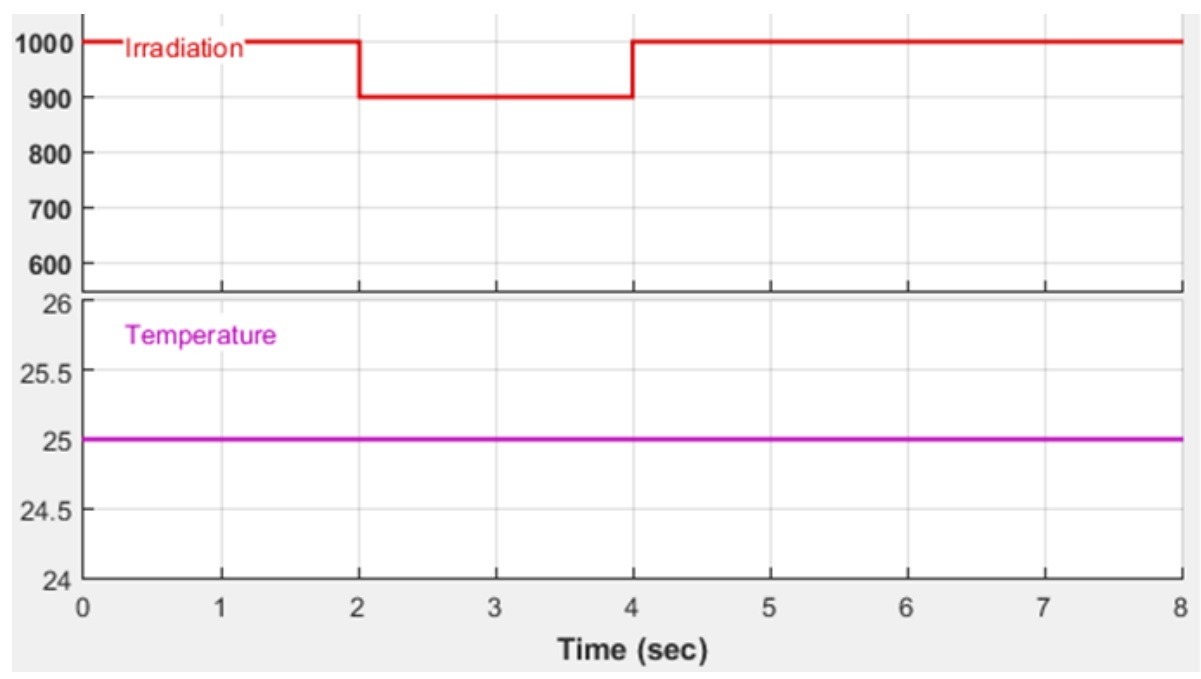

Figure 12. Graph irradiation value disturbance reduced to $900 \mathrm{~W} / \mathrm{m}^{2}$ from $2^{\text {nd }}$ to $4^{\text {th }}$ second

Figure 12. shows the disturbance of the irradiation value on the solar panel where the irradiation value is reduced to $900 \mathrm{~W} / \mathrm{m}^{2}$ from $2^{\text {nd }} \mathrm{s}$ to $4^{\text {th }} \mathrm{s}$. After that, Fig. 13. shows the simulation results from the CC-CV graph with the disturbance of the irradiation value with a value $900 \mathrm{~W} / \mathrm{m}^{2}$.
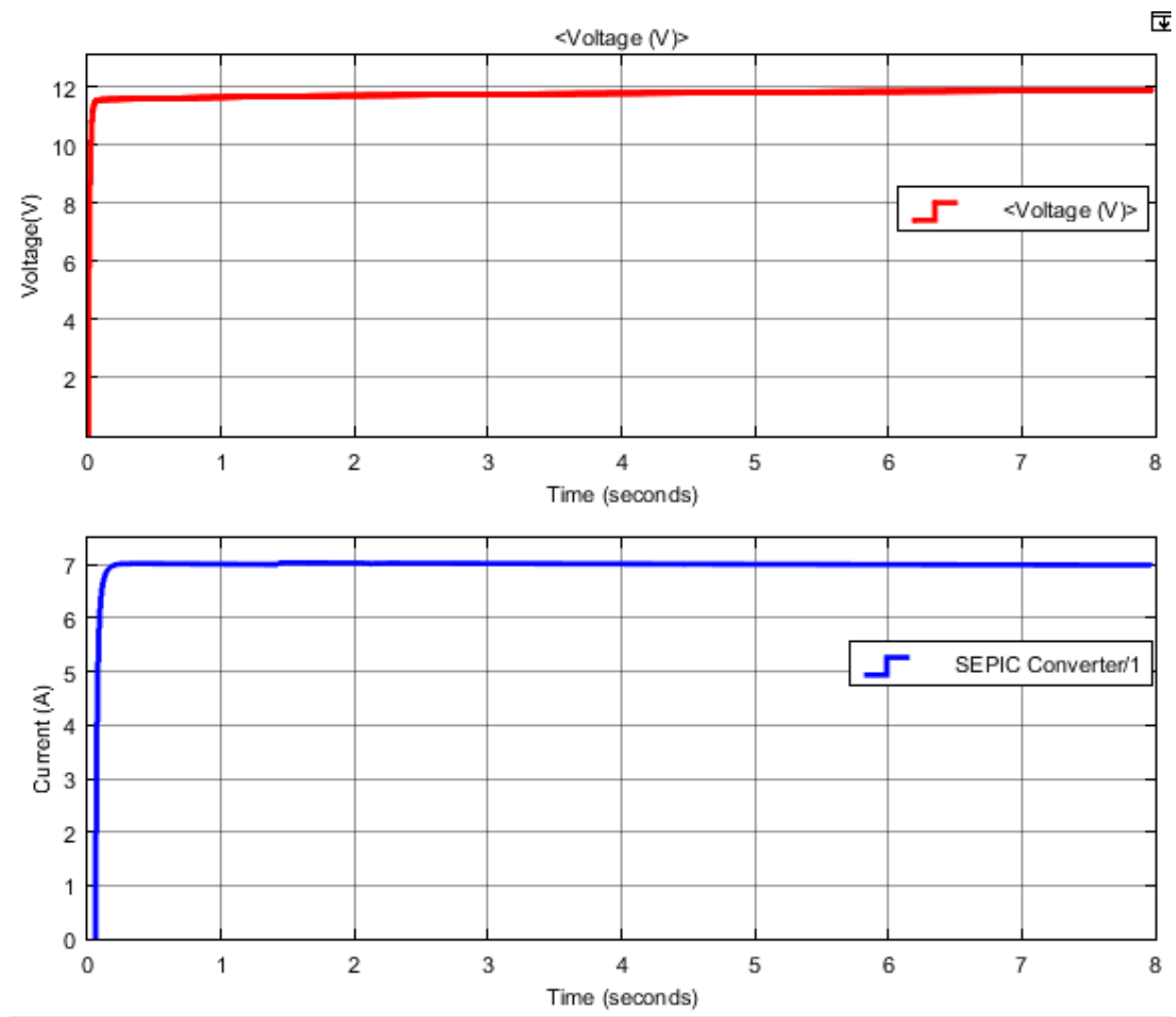

Figure 13 . The simulation results of battery charging with interference value of $900 \mathrm{~W} / \mathrm{m}^{2}$ irradiation and $30 \%$ SOC value

Figure 13. is the result of a CC-CV graphic simulation of charging a lithium ion battery with an initial charging $\mathrm{SoC}$ of $30 \%$. For the initial conditions, the charging method uses CC mode where the current value is 7A. Due to the solar panel irradiation value dropping to $900 \mathrm{~W} / \mathrm{m}^{2}$ from $2^{\text {nd }} \mathrm{s}$ to $4^{\text {th }} \mathrm{s}$ the current value decreased momentarily 


\section{INTEK Jurnal Penelitian}

to $6.995 \mathrm{~A}$, this proves that the control performance is running to deal with disturbances in the solar panel so that battery charging is still going according to plan. For charging voltage when the $\mathrm{SoC}$ is $30 \%$ the value is $11.9 \mathrm{~V}$ and it keeps going up to charge the battery.

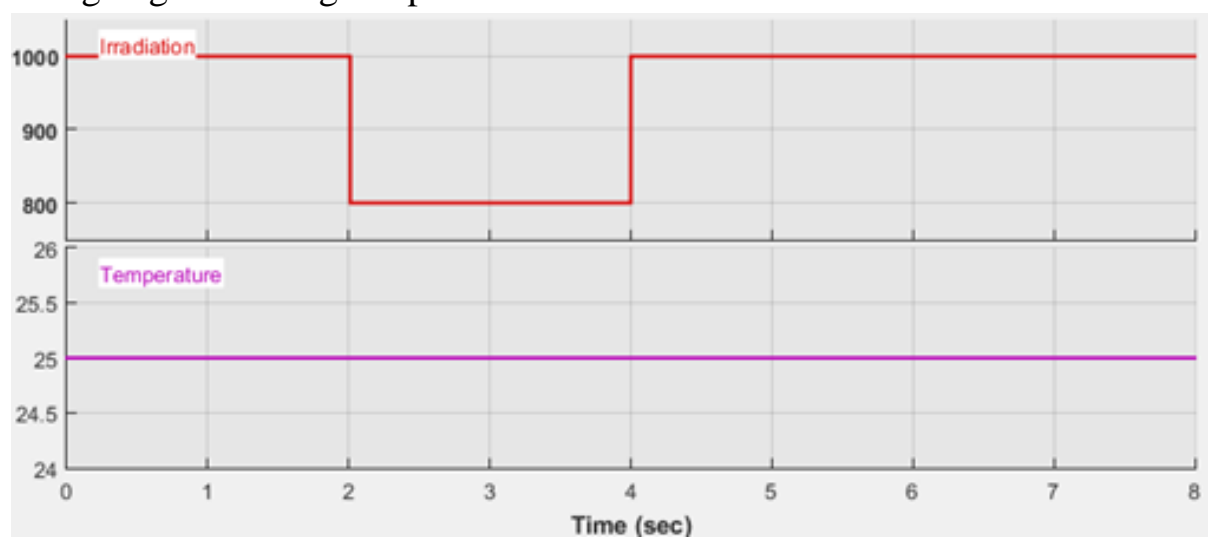

Figure 14. Graph irradiation value disturbance reduced to $800 \mathrm{~W} / \mathrm{m}^{2}$ from $2^{\text {nd }}$ to $4^{\text {th }}$ second

Figure 14. shows the disturbance of the irradiation value on the solar panel where the irradiation value is reduced to $800 \mathrm{~W} / \mathrm{m}^{2}$ from $2^{\text {nd }} \mathrm{s}$ to $4^{\text {th }} \mathrm{s}$. After that, Fig. 15 . shows the simulation results from the CC-CV graph with the disturbance of the irradiation value with a value $800 \mathrm{~W} / \mathrm{m}^{2}$.
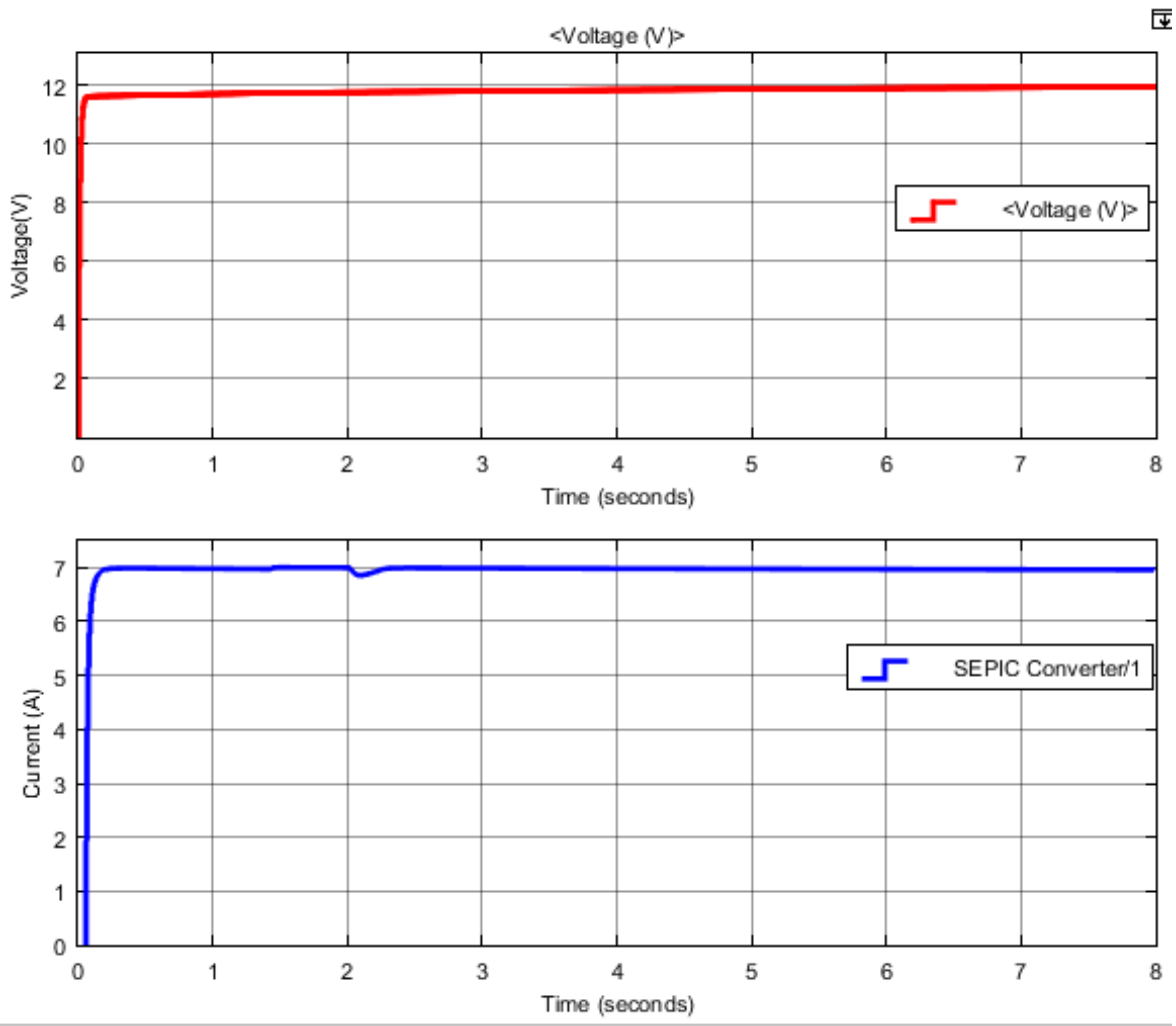

Figure 15. The simulation results of battery charging with interference value of $800 \mathrm{~W} / \mathrm{m}^{2}$ irradiation and $40 \%$ SOC value

Figure 15. is the result of a CC-CV graphic simulation of charging a lithium ion battery with a $40 \%$ of SoC. For the initial conditions, the charging method uses CC mode where the current value is $7 \mathrm{~A}$. Due to the solar panel irradiation value dropping to $800 \mathrm{~W} / \mathrm{m}^{2}$ from $2^{\text {nd }} \mathrm{s}$ to $4^{\text {th }} \mathrm{s}$ the current value decreased momentarily to $6.995 \mathrm{~A}$, this 


\section{INTEK Jurnal Penelitian}

Vol. 8, No. 1, pp. 79-90, April 2021

proves that the control performance is running to deal with disturbances in the solar panel so that battery charging is still going according to plan. For the charging

voltage when the $\mathrm{SoC}$ is $40 \%$ the value is $11.95 \mathrm{~V}$ and it keeps going up to charge the battery.

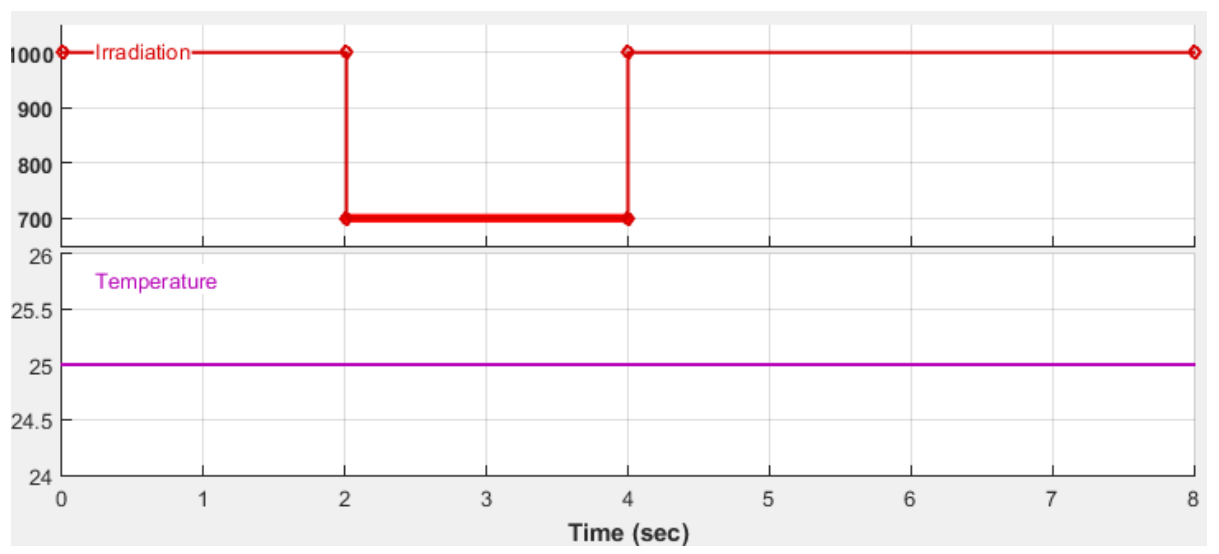

Figure 16. Graph irradiation value disturbance reduced to $700 \mathrm{~W} / \mathrm{m}^{2}$ from $2^{\text {nd }}$ to $4^{\text {th }}$ second

Figure 16. shows the disturbance of the irradiation value on the solar panel where the irradiation value is reduced to $700 \mathrm{~W} / \mathrm{m}^{2}$ from $2^{\text {nd }} \mathrm{s}$ to $4^{\text {th }} \mathrm{s}$. After that, figure
17. shows the simulation results from the CC-CV graph with the disturbance of the irradiation value with a value $700 \mathrm{~W} / \mathrm{m}^{2}$.
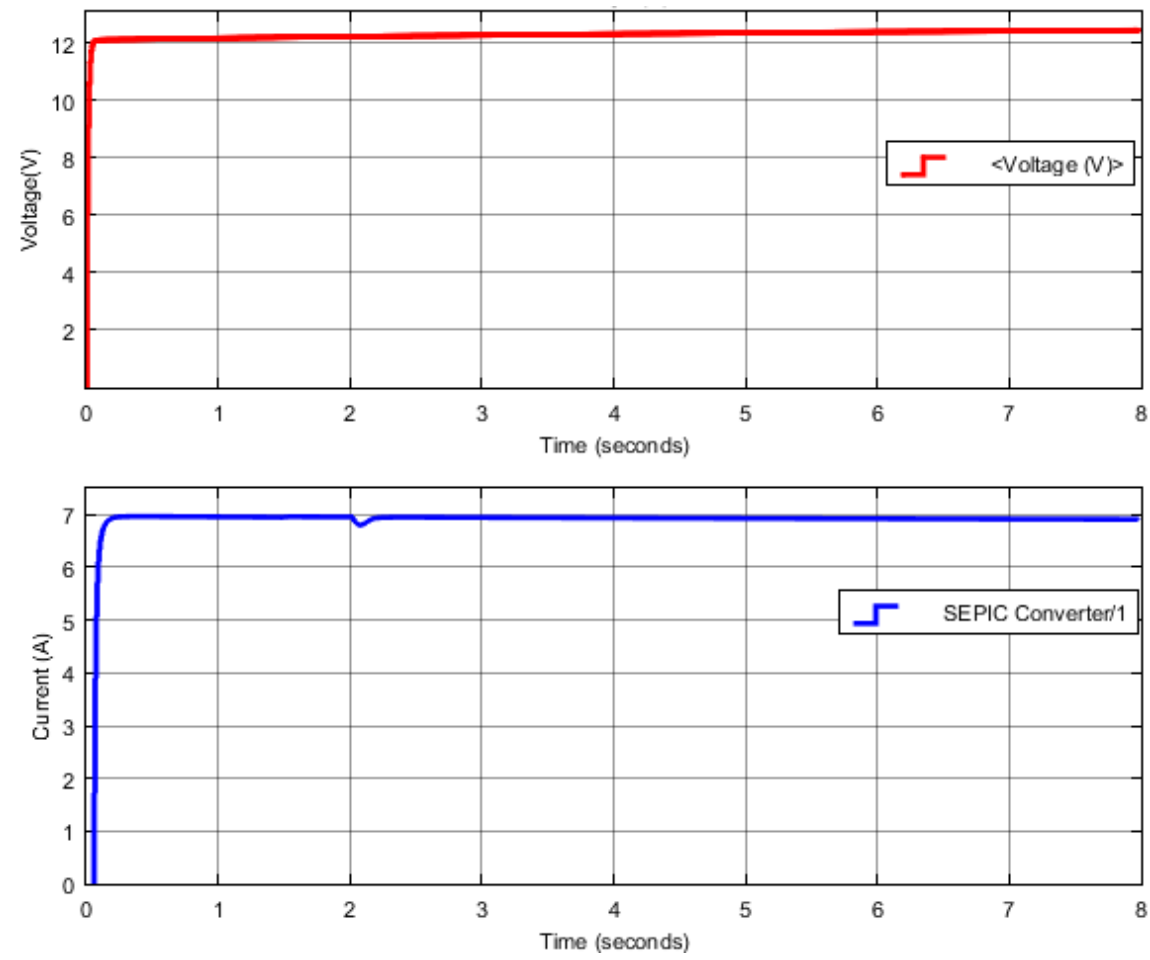

Figure 17. The simulation results of battery charging with interference value of $700 \mathrm{~W} / \mathrm{m}^{2}$ irradiation and $50 \%$ SOC value

Figure 17. is the result of a CC-CV graphic simulation of charging a lithium ion battery with a $50 \%$ of SoC value. For the initial conditions, the charging method uses CC mode where the current value is 7A. Due to the solar panel irradiation value dropping to $700 \mathrm{~W} / \mathrm{m}^{2}$ from $2^{\text {nd }} \mathrm{s}$ to $4^{\text {th }} \mathrm{s}$ the current value decreased momentarily to $6.968 \mathrm{~A}$, this 


\section{INTEK Jurnal Penelitian}

proves that the control performance is running to deal with disturbances in the solar panel so that battery charging is still going according to plan. For the charging voltage when the $\mathrm{SoC}$ is $50 \%$ the value is $12.46 \mathrm{~V}$ and it keeps going up to charge the battery.

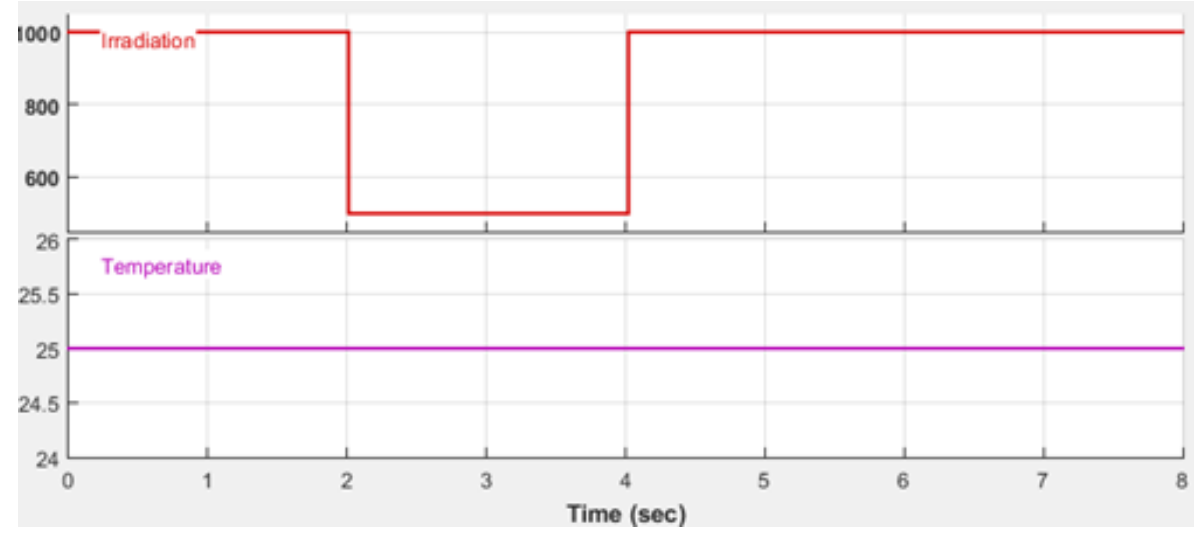

Figure 18. Graph irradiation value disturbance reduced to $500 \mathrm{~W} / \mathrm{m}^{2}$ from $2^{\text {nd }}$ to $4^{\text {th }}$ second

Figure 18. shows the disturbance of the irradiation value on the solar panel where the irradiation value is reduced to $500 \mathrm{~W} / \mathrm{m}^{2}$ from $2^{\text {nd }} \mathrm{s}$ to $4^{\text {th }} \mathrm{s}$. After that, Fig. 19 . shows the simulation results from the CC-CV graph with the disturbance of the irradiation value with a value $500 \mathrm{~W} / \mathrm{m}^{2}$.
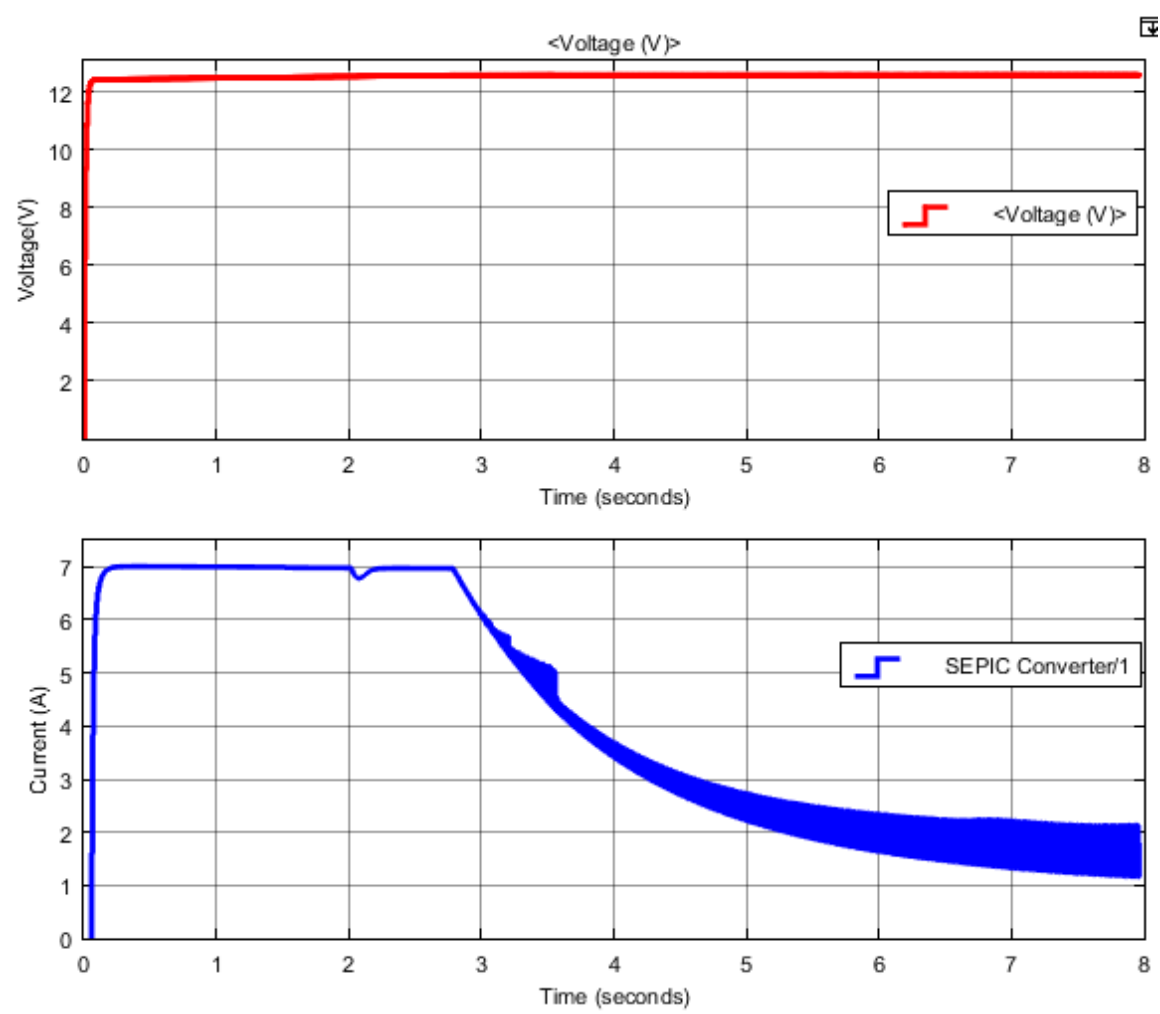

Figure 19. The simulation results of battery charging with interference value of $500 \mathrm{~W} / \mathrm{m}^{2}$ irradiation and $60 \%$ SOC value

Figure 19. is the result of a CC-CV graphics simulation of charging a lithium ion battery with a SoC $60 \%$. For the initial conditions, the charging method uses $\mathrm{CC}$ mode where the current value is 7A. Due to the solar panel irradiation value dropping to $500 \mathrm{~W} / \mathrm{m}^{2}$ from $2^{\text {nd }} \mathrm{s}$ to the $4^{\text {th }} \mathrm{s}$, the current value decreased momentarily to 6.768A, this proves that the control performance is running to deal with disturbances in the solar panel so that 
battery charging is still going on as planned. For the charging voltage when the $\mathrm{SoC}$ is $60 \%$ the value is $12.6 \mathrm{~V}$ and it switches to $\mathrm{CV}$ mode because the charging current starts to drop. So, the voltage to a value $12.6 \mathrm{~V}$ is constant battery voltage when the $\mathrm{SoC}$ value is $60 \%$ and indicates that the battery is fully charged.

\section{Conclusion}

Based on the design and simulating an accurate battery charger SEPIC-coupled inductor using fuzzy type 2, there are some conclusions can be drawn, including:

1. The use of the constant current-constant voltage method for charging lithium ion battery can avoid overcharge battery.

2. Using SEPIC coupled inductor converter equipped with type 2 fuzzy logic control to regulate the voltage and current where the voltage and current are charged at $12.6 \mathrm{~V}$ and $7 \mathrm{~A}$.

3. The switching from constant current to constant voltage method when battery SoC is $60 \%$ the voltage value reaches $12.6 \mathrm{~V}$ and indicates the battery was fully charged

4. Even though the solar panel is disturbance with the irradiation value, the current value drops momentarily with minimum current value of $6.768 \mathrm{~A}$ and returns normal with a value of $7 \mathrm{~A}$.

\section{References}

[1] R P Anggraini, M Z Efendi, and F D Murdianto "Modeling And Simulation Of Miso-Buck Converter Using Anfis On Dc Microgrid Dsitribution System," in IOP Conference Series: Materials Science and Engineering ICIMECE, 2020, DOI: 10.1088/1757-899X/1096/1/012066

[2] Taufik Hidayat, Mohammad Zaenal Efendi, and Farid Dwi Murdianto, "Maximum Power Tracking Point Interleaved Boost Converter Using Cuckoo Search Algorithm On The Nano Grid System," in Journal on Advanced Research in Electrical Engineering, 2021, Vol. 5, No. 1

[3] D J Triandy, E Wahjono, F D Murdianto "Design and Implementation of Bipolar Sepic-Cuk Converter with Fuzzy Logic Control for Battery Charging Application" in IOP Conference Series: Materials Science and Engineering ICIMECE, 2020, DOI: 10.1088/1757-899X/1096/1/012067

[4] Farid Dwi Murdianto, Indhana Sudiharto, and Eni Wulandari "Perfomance Evaluation Zeta Converter Using PI Controller for Energy Management in DC Nanogrid Isolated System," in 2021 INTEK Jurnal Penelitian, 2021, Vol. 8, No. 1, pp.37-42, DOI: http://dx.doi.org/10.31963/intek.v8il.2651
[5] Saurabh Kumar, Rajat Kumar, and Navdeep Singh "Perfomance of Closed Loop SEPIC Converter with DC-DC Converter for Solar Energy System," in 2017 International IEEE, 978-1-5090- 4426-9/17

[6] Indhana Sudiharto, Farid Dwi Murdianto, Yahya Chusna Arif, Agus Tri Prasetyo, and Hendik Eko H S "Design and implementation SEPIC Converter Using PI Controller for Solution Power Quality Improvement," in 2019 International Conference on Science and Technology ICST

[7] Kaffin Uwais Ahmad, Suhariningsih, and farid Dwi Murdianto "Hybrid Modified PSO - IC Methods Based MPPT to Overcome Partial Shading" in International Journal on Electrical Engineering and Informatics, 2021, Vol. 13, No. 2, DOI: 10.15676/ijeei.2020.13.2.11

[8] Van-Binh Vu., Duc-Hung Tran., \& Woojin Choi "Implementation of the Constant Current and Constant Voltage Charge of Inductive Power Transfer Systems with the DoubleSided LCC Compensation Topology for Electric Vehicle Battery Charge Applications," in 2017 IEEE International, 2017, DOI10.1109/TPEL.2017.2766605

[9] Neily Itsqiyah Mufa'ary, Indhana Sudiharto, and Farid Dwi Murdianto "Comparison of FLC and ANFIS Methods to keep Constant Power Based on Zeta Converter," in 2021 INTEK Jurnal Penelitian, 2021, Vol. 8, No. 1, pp. 21-29, DOI: http://dx.doi.org/10.31963/intek.v8il.2701

[10] H. Suryoatmojo "Design Li-Po Battery Charger with Buck Converter under Partially CC-CV Method," in 2020 International Seminar on Intelligent Technology and Its Applications, 2020. ISITIA, 2020, 978-1-728-1-7413-6/20

[11] Muhammad Khamim Asy'ari and Ali Musyafa' "Design of Buck Converter Based on Interval Type-2 Fuzzy Logic Controller," in 2018 International Seminar on Intelligent Technology and Its Applications, 2018. ISITIA, 978-1-5386-7654-7/18

[12] Farid Dwi Murdianto., Ainur Rofiq Nansur., \& Alfis Syah Laili Hermawan "Modeling and Simulation of MPPT Coupled Inductor Sepic Converter using Flower Pollination Algorithm (FPA) Method in DC Microgrid System," in 2017 International Electronics Symposium on Engineering Technology and Applications IES-ETA, 2017. 978-1-5386-0712-1/17

[13] Sara Hasanpour., Alfred Baghramian., \& Hamed Mojallali “A New High Gain Coupled-Inductor SEPIC Converter for a Microgrid System," in 2017 Power Electronics, Drive systems \& Technologies Conference, 2017. PEDSTC, Mahshhad, Iran, 294299. 978-1-5090-5766-5-17

[14] Hossein Ardi., Ali Ajami., \& Mehran Sabahi “A Sepic Based High Step-Up DC-DC Converter integrating coupled inductor for renewable energy applications," in 2017 Power Electronics, Drive systems \& Technologies Conference, 2017. PEDSTC, Mahshhad, Iran 978-1-5090-5766-5-17

[15] Ali Monstaan, Jing Yuan, Yam Siwakoti, Soroush Esmaeili, and Frede Blaabjerg "A Trans-Inverse Coupled-Inductor Semi SEPIC DC/DC Converter with Full Control Range" in 2019 IEEE DOI 10.1109/TPEL.2019.2917306

[16] Saeed M. Akhmadan, Reza P. R. Hasanzadeh, and Mayorkinos Papaelias, "Arbitary Crack Depth Profiling through ACFM Data using Type-2 Fuzzy Logic and PSO Algorithm," in 2018 IEEE

[17] K.A. Naik., \& C.P. Gupta "Performance Comparison of Type-1 and Type-2 Fuzzy Logic Systems," in 2017 International Conference on Signal Processing, Computing and Control (ISPCC), 2017, 978-1-5090-5838-9/17

[18] Andry Meylani, Ade Silvia Handayani, and Ciksadan "Perbandingan Kinerja Sistem Logika Fuzzy Tipe-1 dan Interval Tipe-2 pada Aplikasi Mobile Robot," in 2017 Annual Research Seminar, , ISBN: 979-587-705-4

[19] Mohammed Y. Hasan, Hazem I. Ali, Haider M. Jassim, "Hybrid h-infinity Fuzzy Logic Controller Design," in 2020 Journal of Engineer Science and Technology, Vol. 15, No. 1. 


\section{INTEK Jurnal Penelitian}

[20] Farid Dwi Murdianto., Ainur Rofiq Nansur., Alfis Syah Laili Hermawan., \& Rangga Eka Setiawan "Comparison Method of Flower Pollination Algorithm, Modified Particle Swarm Optimization and Perturb \& Observe in MPPT Coupled Inductor Sepic Converter on DC Microgrid Isolated System," in 2017 International Conference on Advanced Mechatronics, Intelligent Manufacture, and Industrial Automation (ICAMIMIA), 2017. 978-1-5386-2729-7/17

[21] Ainur Rofiq Nansur., Alfis Syah Laili Hermawan., \& Farid Dwi Murdianto "Constant Voltage Control Using Fuzzy Logic Controller (FLC) to Overcome the Unstable Output Voltage of MPPT in DC Microgrid System," in 2018 International Electronics Symposium on Engineering Technology and Applications IES-ETA, 2018, 978-1-5386-8083-4/18
[22] Lunde Ardhenta., Ramadhani Kurniawan Subroto., \& Irfan Al Faruqi "An Improved PID Controller Using Fuzzy Logic for SEPIC DC/DC Converter," in 2019 International Conference on Advanced Mechatronics, Intelligent Manufacture, and Industrial Automation (ICAMIMIA), 2019, 978-1-7281-3090-3/19

[23] Meryem Oudda and Abdeldjebar Hazzab "Fuzzy Logic Control of a SEPIC Converter for a Photovoltaic System," in 2016 Journal of Fundamentals of Renewable Energy and Applications, DOI: 10.4172/2090-4541.1000212

[24] Irianto, Farid Dwi Murdianto, Epyk Sunarno, and Dewinta Dwi Proboningtyas "Comparison Method of PI, PID and Fuzzy Logic Controller to Maintain Speed Stability in Single Phase Induction Motor," in 2021 INTEK Jurnal Penelitian, 2021, Vol. 8, No. 1, pp. 7-16, DOI: http://dx.doi.org/10.31963/intek.v8il.2687 